\author{
Renata Rettinger \\ Uniwersytet Pedagogiczny \\ im. Komisji Edukacji Narodowej \\ w Krakowie
}

\title{
Przedsiębiorczość mieszkańców wybranych regionów turystycznych Kuby
}

\section{Entrepreneurship of population living in selected tourist regions of Cuba}

\begin{abstract}
Streszczenie
Kuba jest jednym z najważniejszych regionów turystyki wypoczynkowej na świecie, charakteryzuje się bardzo dużą atrakcyjnością przyrodniczą i pozaprzyrodniczą. Ma bardzo dobre zagospodarowanie turystyczne, które tworzą w większości hotele all inclusive, kontrolowane ekonomicznie przez kubańskie spółki z kapitałem mieszanym. Po rozpadzie ZSRR Kuba stanęła w obliczu ostrego kryzysu ekonomicznego, co spowodowało zmiany w jej systemie gospodarczym. Najważniejszą z nich było wyrażenie zgody na prowadzenie działalności gospodarczej (samozatrudnienie) w branży turystycznej. Głównym celem niniejszego opracowania jest próba określenia uwarunkowań wpływających na kształtowanie się postaw przedsiębiorczych ludności miejscowej w regionach o różnym poziomie wykształcenia funkcji turystycznej. Analizę poszerzono o klasyfikację różnych form gospodarczej działalności.
\end{abstract}

\begin{abstract}
Cuba is one of the most important regions for leisure travel in the world; it is characterized by a large level of attractiveness, both natural and man-made. It has a very good tourist management, which mostly include high-class all-inclusive hotels economically controlled by Cuban companies with a mixture of foreign and home capital. After the dissolution of USSR, Cuba was faced with a severe economical crisis which led to changes in the country's economy and governing system. The most important of which was the approval of business activity (self employment) in the field of tourism. The main goal of the study is to attempt to specify the conditions influencing the development of the basic entrepreneurship in local communities in the areas where tourist functions advanced differently; the analysis was further expanded by adding classification of different forms of business activity.
\end{abstract}

Słowa kluczowe: casas particulares; Kuba; przedsiębiorczość; turystyka

Key words: casas particulares; Cuba; entrepreneurship; tourism

\section{Wprowadzenie}

Kuba jest jednym z ważniejszych regionów turystyki wypoczynkowej na świecie. Według regionalizacji turystycznej przeprowadzonej przez UNWTO należy ona do regionu Ameryka i subregionu Karaiby. Charakteryzuje się wysoką atrakcyjnością przyrodniczą oraz bogatym dziedzictwem kulturowym. W kraju tym największą rolę odgrywa turystyka pobytowa o charakterze wypoczynkowym, natomiast całkowicie została zmarginalizowana turystyka morska 
(rejsy okrężne). Kuba ma bardzo dobre zagospodarowanie turystyczne, które tworzą przede wszystkim duże kompleksy hotelowe typu all inclusive, stanowiące enklawy turystyczne. W większości hotele te należą w 50\% do państwa oraz zagranicznych inwestorów bądź też są przez nich administrowane, w związku z tym obserwuje się przenikanie zysków do krajów wysoko rozwiniętych. Niestety ten charakter turystyki powoduje odsunięcie społeczności miejscowej od zysków generowanych przez turystykę. Na podstawie powyższych rozważań można wnioskować, że sytuacja w kubańskiej branży turystycznej hamuje działania przedsiębiorcze miejscowej ludności. Jednak badania wskazują na zupełnie odwrotną tendencję, z każdym rokiem wzrasta liczba prywatnych osób prowadzących działalność gospodarczą w branży turystycznej, stał się to możliwe dzięki zmianom polityki gospodarczej kraju po $1993 \mathrm{r}$.

Głównym celem opracowania jest próba określenia uwarunkowań wpływających na kształtowanie się postaw przedsiębiorczych miejscowej ludności w regionach o różnym poziomie wykształcenia funkcji turystycznej. Analizę poszerzono o klasyfikację różnych form gospodarczej działalności. Opracowanie dotyczy zagadnień aktywizacji gospodarczej ludności miejscowej przez turystykę w układzie regionalnym oraz lokalnym.

\section{Uwarunkowania rozwoju przedsiębiorczości na Kubie}

Jednym z ważniejszych czynników decydujących o możliwościach podejmowania działalności gospodarczej jest polityka władz kraju. W przypadku Kuby jest to czynnik podstawowy, ponieważ $\mathrm{w}$ dalszym ciągu jest to gospodarka centralnie sterowana $\mathrm{z}$ niewielkimi elementami mechanizmów rynkowych.

Bardzo ważnym momentem w historii Kuby, który w sposób zasadniczy odmienił nie tylko układ polityczny i gospodarczy kraju, była rewolucja kubańska (1959 r.), która spowodowała wprowadzenie systemu centralnie sterowanej gospodarki socjalistycznej z całkowitą eliminacją własności prywatnej. Jedynie niewielka liczba osób uzyskała zgodę na prowadzenie własnych przedsiębiorstw handlowych (Scarpaci, 2009). W 1968 r. zamknięto wszystkie 58 tys. prywatnych przedsiębiorstw i w większości zostały one upaństwowione (Gustafsson, 2011). Od początku lat 60. nastąpiła marginalizacja sektora turystycznego, a w szczególności przyjazdowego ruchu zagranicznego, na korzyść turystyki krajowej. Następne dekady charakteryzowały się bardzo niskim poziomem zagranicznego ruchu turystycznego (w większości z krajów socjalistycznych) oraz olbrzymim regresem w zakresie infrastruktury turystycznej. To miało ogromny wpływ na kierunek rozwoju turystyki, trzeciego co do ważności sektora gospodarczej działalności na wyspie, po cukrownictwie i produkcji cygar. Kuba utraciła swoją wysoką pozycję w regionie Karaibów jako kraj o największym ruchu turystycznym i wpływach generowanych przez ten sektor.

Dopiero lata 80. przyniosły znaczące zmiany w prawodawstwie, które otworzyły kraj dla inwestycji zagranicznych w branży turystycznej. W 1982 r., na mocy ustawy nr 50, zezwolono na współpracę z firmami czy też kapitałem zagranicznym, w związku z tym zaczęły powstawać spółki kapitału mieszanego typu joint venture. W 1987 r. powstała jedna z największych i do dzisiaj funkcjonujących spółek Cubanacan (Korporacja Handlu Zagranicznego i Turystyki), a w maju 1990 r. spółka otworzyła pierwszy hotel w Varadero, w porozumieniu z hiszpańskim inwestorem Melia. W kolejnych latach oddano są do użytku dwa następne hotele o łącznej pojemności 1400 miejsc noclegowych (Cervino, Cubillo, 2005). W 1988 r. do życia została powołana Gaviota spółka z udziałem kapitału zagranicznego. Równocześnie podpisywano liczne kontrakty menadżerskie m.in. z partnerami niemieckimi (LTI) oraz jamajskimi (Superclubs). W przypadku Kuby trudno jest mówić o konkurencyjności podmiotów gospodarczych działających w branży turystycznej, wiadomym jest, że jedynie z przyzwolenia politycznego mogły powstawać instytucje lub przedsiębiorstwa turystyczne. 
Rok 1989 był przełomem w gospodarce Kuby, początkiem bardzo głębokiego kryzysu gospodarczego. Powodem tej sytuacji był rozpad bloku socjalistycznego w Europie, z którym to blokiem, zwłaszcza z ZSRR, Kuba była związana licznymi umowami handlowymi. Zerwanie korzystnych dla Kuby umów handlowych skutkowało natychmiastowym wstrzymaniem napływu dewiz oraz ostrym deficytem wielu produktów na rynku wewnętrznym (ropa naftowa, produkty żywnościowe). Ta skomplikowana sytuacja wymusiła na władzach Kuby wprowadzenie tzw. okresu specjalnego w czasach pokoju, w trakcie którego dokonano szeregu reform systemu gospodarczego.

Początek lat 90. XX w. przyniósł kolejne regulacje w zakresie nowych form działalności gospodarczej na Kubie. Do najważniejszych należały przepisy o możliwości powstawania przedsiębiorstw z kapitałem mieszanym (joint ventures), działającym przede wszystkim w branży turystycznej lub w szeroko rozumianym otoczeniu (Perez-Lopez, 1994, 2001).

Następnym krokiem w zakresie liberalizacji rynku kubańskiego było wyrażenie zgody na sprzedaż produktów rolniczych przez prywatnych rolników. Zabieg ten miał poprawić sytuację w zakresie wyżywienia ludności, a także jakość życia na obszarach wiejskich. Drugim sektorem gospodarczej działalności człowieka, w którym wprowadzono bardzo szybkie reformy, była turystyka zagraniczna. Od początku lat 90. praca w turystyce lub sektorach z nią związanych stała się jedyną możliwością godnego zarobkowania (that is where the food and money is) (Gustafsson, 2011; Spencer, 2010). Bardzo wysoki poziom ubóstwa, brak środków do utrzymania spowodowały konieczność szukania możliwości zarobkowania na własną rękę, a to wyzwoliło w ludziach, przy niewielkiej aprobacie władz politycznych kraju, postawy przedsiębiorcze.

Priorytetowym zagadnieniem było umożliwienie samozatrudnienia (cuentapropistas), które spowodowało podejmowanie działalności gospodarczej przez Kubańczyków (Scarpaci, 1995, 2009). Rząd kubański zezwolił na samozatrudnienie w obrębie 181 zawodów, z czego najwięcej było związanych z turystyką i rolnictwem (Kederstedt, 2012). Wyrażenie zgody na prowadzenie działalności gospodarczej przyniosło szereg wymiernych skutków dla gospodarki kubańskiej, m.in.: odciążenie systemu płacowego przez redukcję części zatrudnienia na stanowiskach w państwowych sektorach, zmniejszenie bezrobocia powstałego po redukcji zatrudnienia w cukrownictwie oraz zwiększenie wpływów podatkowych od prywatnych przedsiębiorców (Peters, 2012). Prywatna przedsiębiorczość jest więc akceptowana przez władze państwowe, a wynika to z możliwość przechwytywania znacznej części dewiz przesyłanych przez rodziny mieszkające na terenie Stanów Zjednoczonych. Te środki finansowe są bardzo często przeznaczane na rozpoczęcie lub dofinansowanie działalności gospodarczej (Taylor, McGlynn, 2009). Kolejnym ważnym powodem jest uzupełnienie rynku usługami, których nie może dostarczyć państwo. To zapewnia szeroki zakres usług zarówno dla mieszkańców, jak i turystów, czyli jest niezbędnym elementem bazy paraturystycznej.

Pomimo wprowadzanych reform gospodarczych, mających na celu liberalizację rynku, przedsiębiorcy kubańscy borykają się z licznymi obostrzeniami. Z każdy rokiem wzrastają obciążenia podatkowe przedsiębiorstw, co nawet spowodowało spadek liczby podmiotów gospodarczych o $23 \% \mathrm{w}$ pierwszych czterech latach obowiązywania nowych podatków. Według różnych badań, przeciętny przedsiębiorca musi przeznaczać ok. 42\% swoich dochodów na podatki i opłaty licencyjne, jeszcze jednym utrudnieniem są liczne kontrole, np. dotyczące prowadzonej dokumentacji. Liczne nadużycia spowodowały powołanie w $2001 \mathrm{r}$. Ministerstwa Nadzoru i Kontroli mającego na celu zmniejszenie zasięgu nieformalnej sfery i nadużyć. W 2007 r. Ministerstwo Pracy nasiliło sankcje za korupcję i kradzieże.

W 2008 r. rządy na Kubie zostały przekazane w ręce Raula Castro i rozpoczął się proces dalszej intensyfikacji wprowadzania reform w różnych sektorach gospodarki kraju. Bardzo 
ważnym zagadnieniem stało się tworzenie klimatu sprzyjającego rozwojowi przedsiębiorczości, za co odpowiada system władzy. Zmiana przepisów prawnych regulujących powstawanie i prowadzenie prywatnych form działalności gospodarczej to pierwszy etap, który został wprowadzony bardzo szybko i sprawnie. Niestety mieszkańcy nie otrzymali ze strony państwa żadnej pomocy w zakresie instrumentów finansowych. Na Kubie w rzeczywistości inicjatywy o charakterze gospodarczym są ogłaszane przez władze polityczne kraju, chociaż realizowane są lokalnie. Istnieje tu prawidłowość, że społeczeństwo angażuje się w ogłoszone i rozpoczęte programy, a nie poszukuje aktywnie możliwości projektowania i wdrażania programów (Rosendahl, 1997).

\section{Instrumenty finansowe a przedsiębiorczość}

Bardzo ważnym czynnikiem warunkującym kształtowanie się postaw przedsiębiorczych jest konieczność posiadania kapitału początkowego, który pozwoli na rozpoczęcie działalności gospodarczej. Społeczeństwo kubańskie nie ma środków finansowych, dlatego też bardzo dużą rolę odgrywa pomoc diaspory kubańskiej w USA, która wspomaga finansowo swoich bliskich na wyspie. Szacuje się, że 80\% mieszkańców wyspy otrzymuje taką pomoc (Spadoni, 2003). W regionie Ameryki Łacińskiej zjawisko przesyłania przekazów pieniężnych jest powszechne. Według szacunków, rocznie 69 mld dolarów dociera w ten sposób do rodzin w Ameryce Łacińskiej, w ośmiu krajach regionu przekazy stanowią 10\% PKB (Eckstein, 2009). Rolę przekazów pieniężnych od rodzin podkreśla dodatkowo fakt, że przewyższają one kwotę pomocy finansowej kierowanej do tych krajów, a w niektórych przypadkach nawet wartość pożyczek i kredytów bankowych. Przekazy pieniężne nie tylko uzupełniają braki w budżetach rodzinnych, ale także są bardzo ważnym źródłem dewiz na rynku walutowym krajów.

Przez wiele lat posiadanie dolarów na Kubie było nielegalne, dopiero w 1993 r. nastąpiła legalizacja tej waluty, co zintensyfikowało przekazy finansowe od rodzin w USA. Najwięcej dolarów dotarło na wyspę tuż po upadku ZSRR, czyli w czasach największego kryzysu. Według niektórych źródeł, na początku lat 90. roczna wartość przekazów wynosiła 50 mln dolarów, a na początku nowego wieku ok. 1 mld USD. W latach 1994-2003 kubańska diaspora przekazywała więcej funduszy, niż wynosiła wartość wszystkich zagranicznych inwestycji na wyspie i pomoc innych krajów. Rząd amerykański próbował regulować i kontrolować wielkość przekazów finansowych, ograniczając je do 1200 dolarów rocznie tylko dla bliskich krewnych. Przepisy te skutecznie omijano, przesyłając pieniądze chociażby przez prywatnych kurierów, i ostatecznie w 2009 r. zniesiono te ograniczenia.

W celu przychwycenia części amerykańskiej waluty powstały państwowe sklepy (Tiendas de Recuperacio'n de Divisas - TRDs), oferujące szeroki asortyment produktów żywnościowych i przemysłowych za dolary. Na zakupy w tych sklepach kubańczycy przeznaczali $75-80 \%$ wartości przekazów finansowych - była to jedna z bardziej skutecznych form przechwytywania twardej waluty przez państwo. W 2003 r. w Hawanie funkcjonowało 300 takich placówek, natomiast w pozostałej części kraju - 1 tys. (Eckstein, 2009). Wartość sprzedaży w sklepach dolarowych w 1998 r. wynosiła 870 tys. dolarów, a pięć lat później 1,3 mln dolarów. Drugim sposobem były kantory wymiany walut CADECAs (Cajas de Cambio), w których obowiązywał zaniżony kurs państwowy, stworzono także możliwość zakładania lokat bankowych w dolarach. Kubańczycy starają się unikać formalnej drogi przekazywania środków finansowych na Kubę, ponieważ wiąże się to z bardzo wysokimi opłatami manipulacyjnymi, najczęściej więc w dalszym ciągu wykorzystują prywatnych kurierów. Koszt transferu 1 dolara na wyspę wynosi 19 centów i jest ponoszony przez mieszkańców wyspy, do których jest ta pomoc kierowana. 


\section{Przedsiębiorstwa na Kubie - zróżnicowanie ilościowe}

W różnych okresach czasu liczba małych przedsiębiorstw na Kubie znacznie się wahała. Najniższa była przed kryzysem ekonomicznym (1989 r.) i szacowano ją na poziomie 10-15 tys. osób - były to przede wszystkim zakłady fryzjerskie i kosmetyczne, natomiast już w $1996 \mathrm{r}$. 209 tys. Kubańczyków pracowało w prywatnych przedsiębiorstwach. Aktualnie znacznie obniżyła się dynamika tego zjawiska i w 2010 r. liczba osób pracujących w prywatnym sektorze wynosiła 371 tys. w 143 tys. podmiotów gospodarczych (Peters, 2012). Mniejsza dynamika powstawania nowych podmiotów gospodarczych wynika $\mathrm{z}$ faktu ograniczania liczby przyznawanych nowych licencji przez organy samorządu terytorialnego. Z danych publikowanych przez Ministerstwo Pracy wynika, że spośród prywatnych podmiotów gospodarczych na transport osób i towarów przypada $16 \%$, na usługi gastronomiczne - 15\%, na handel produktami rolnymi $-5 \%$, a na świadczenie usług noclegowych $-5 \%$.

Nowe przepisy wprowadzone w okresie władzy Raula Castro umożliwiały zatrudnianie pracowników przez prywatnych przedsiębiorców. Wcześniej jedynie właściciele punktów gastronomicznych - paladares - mogli zatrudniać ograniczoną liczbę pracowników (Scarpaci, 2009). Zwiększono pojemność obiektów gastronomicznych z 12 do 20, a w konsekwencji do 50 miejsc konsumpcyjnych, zniesiono zakaz podawania wołowiny i skorupiaków. Zezwolono na wynajem pomieszczeń do prowadzenia działalności gospodarczej. Towary i usługi mogą być sprzedawane zarówno odbiorcom prywatnym, jak i państwowym oraz firmom zagranicznym. Przedsiębiorcy są zobligowani do płacenia podatków i wspomagania funduszu zdrowotnego i emerytalnego.

Tab. 1. Liczba przedsiębiorców w latach 1993-2012 na Kubie

\begin{tabular}{|c|c|}
\hline Lata & Liczba przedsiębiorców \\
\hline 1993 & $10000-15000$ \\
\hline 1995 & 170000 \\
\hline 1996 & 209606 \\
\hline 1999 & 156600 \\
\hline 2001 & 152300 \\
\hline 2003 & 151000 \\
\hline 2005 & 169400 \\
\hline 2006 & 152600 \\
\hline 2007 & 138400 \\
\hline 2008 & 141600 \\
\hline 2009 & 143800 \\
\hline 2010 & 157371 \\
\hline 2011 & 357000 \\
\hline 2012 & 385775 \\
\hline
\end{tabular}

Źródło: Peters (2012b). 


\section{Model rozwoju turystyki na Kubie jako jeden z czynników warunkujących kształtowanie postaw przedsiębiorczych}

Obecnie turystyka na Kubie jest głównym źródłem dochodów, dewiz oraz największym pracodawcą. W 2012 r. kraj ten odwiedziło 2,8 mln turystów zagranicznych pochodzących głównie z Kanady i Europy Zachodniej. Spośród wszystkich krajów regionu karaibskiego Dominikana i Kuba należą do najlepiej zagospodarowanych i najczęściej odwiedzanych przez turystów (Rettinger, 2012). Dominującymi typami są turystyka wypoczynkowa (Varadero, Holguin, Cayo Coco, Cayo Santa Maria, Cayo Largo) oraz turystyka miejska (Hawana, Trynidad, Cienfuegos, Santiago de Cuba). W regionach turystyki wypoczynkowej zlokalizowanych w krajach biednych, słabo rozwiniętych, przy znacznym braku środków finansowych na inwestycje w zakresie zagospodarowania turystycznego wyraża się zgodę na zagraniczne inwestycje wielkich touroperatorów. To niestety doprowadza do znacznego wycieku dewiz poza granice kraju, co w znacznym stopniu obniża efekty mnożnikowe wywołane przez turystykę (Page, 2011; Mowforth, Munt, 2009). W przypadku Kuby problem ten ma inny charakter, ponieważ funkcjonują tam obiekty hotelarskie z kapitałem mieszanym, udział państwa kubańskiego waha się na poziomie 50\%, co w znacznym stopniu ogranicza odpływ dewiz. Niestety, nie przynosi to wymiernych korzyści dla społeczeństwa, ponieważ państwo kontroluje wszelkie przepływy finansowe, nawet wynagrodzenia pracownikom kubańskim są wypłacane przez państwowe agencje pośrednictwa pracy. Należy sobie zadać pytanie, kto korzysta z rozwoju turystyki. Bardzo często turystyka jednak nie tylko nie przynosi zysków ekonomicznych ludności miejscowej, a wręcz odwrotnie - prowadzi do rozwarstwienia społeczeństwa i ograniczenia dostępu do dóbr przyrodniczych, które są nadmiernie wykorzystywane przez turystów.

Zasadniczym problemem jest model rozwoju turystyki na Karaibach, gdzie przeważają dwa kierunki rozwojowe: turystyka wypoczynkowa i rejsy okrężne. W pewien sposób zasadniczo ogranicza to możliwości działań przedsiębiorczych w zakresie obsługi ruchu turystycznego. W przypadku rejsów okrężnych: statki są specyficznymi enklawami turystycznymi, gdzie wszystkie potrzeby turysty są zaspokajane na statku przez touroperatora, a jedynie w momencie wyjścia na ląd istnieją możliwości wspierania lokalnej przedsiębiorczości przez zakup towarów i usług. Według szacunków, przeciętny uczestnik rejsu okrężnego zostawia na lądzie ok. 150 dolarów, które przeznacza na zakupy pamiątek oraz usługi gastronomiczne i transportowe.

\section{Podmioty gospodarcze działające w branży turystycznej}

Zmiany w systemie gospodarczym Kuby umożliwiły powstanie i funkcjonowanie różnych przedsiębiorstw branży turystycznej. Na potrzeby niniejszego opracowania zawężono zagadnienie do małych przedsiębiorstw, które bardzo często są jednoosobowe. Takie warunki spełniają przede wszystkim obiekty noclegowe powstałe w prywatnych domach lub mieszkaniach Kubańczyków (casa particulares) lub domowe jadłodajnie (paladares). Powyższe podmioty tworzą sferę formalną rynku turystycznego, czyli są zarejestrowane i objęte zobowiązaniami podatkowymi. Lata 1993 i 1996 oznaczają wprowadzanie przepisów dotyczących prowadzenia działalności gospodarczej w formie wynajmu kwater prywatnych przez mieszkańców Kuby. Władze Kuby były bezpośrednio zainteresowane powstawaniem dużych ośrodków turystycznych typu all inclusive o charakterze enklaw turystycznych

Casas particulares powstały jako ważne uzupełnienie bazy noclegowej. Pierwsze obiekty powstały w 1993 r. - w ciągu pierwszych pięciu lat na terenie Hawany funkcjonowało 2284 casas particulares, a w pozostałej części Kuby jedynie 1537. Kolejne lata to dalszy wzrost liczby tych obiektów, szczególnie poza Hawaną: w 2002 r. w stolicy zarejestrowanych było 
2730 kwater prywatnych, natomiast w pozostałej części kraju, 4980. Casas particulares cieszą się niesłabnącą popularnością wśród turystów zagranicznych, chcących poznać autentyczną Kubę.

Mowforth i Munt (2009) określają tę formę zagospodarowania turystycznego jako element aktywizujący społeczności lokalne, istotne źródło dochodów indywidualnych przedsiębiorców oraz źródło w znacznym stopniu zasilające budżet państwowy przez wpływy podatkowe. Jest to jedna z dróg podnoszenia jakości życia społeczności lokalnych, które charakteryzują się bardzo niskimi dochodami, gdzie znaczna część społeczeństwa żyje na granicy ubóstwa. Skandalicznie niskie zarobki w sektorze państwowym zmusiły część Kubańczyków do podjęcia własnej działalności gospodarczej lub przenoszenia się do formalnego i nieformalnego sektora turystycznego (Uriarte, 2008). Jest regułą, że właściciel casas particulares w historycznej części Hawany jest w stanie zarobić w jeden dzień tyle, co w miesiąc na państwowej posadzie. W literaturze jest cytowanych szereg przykładów jeszcze bardziej podkreślających te dysproporcje, np. w seksturystyce.

\section{Regionalne zróżnicowanie rozwoju przedsiębiorczości na Kubie}

Turystyka jest zjawiskiem gospodarczym wykazującym się silnym stopniem koncentracji przestrzennej, wynikającym z atrakcyjności turystycznej obszarów. W przypadku Kuby i wielu wysp karaibskich za najatrakcyjniejsze uważa się tereny nadmorskie oraz miasta historyczne. W ostatnich latach do tej grupy dołączyły jeszcze obszary, na których rozwija się szeroko rozumiana ekoturystyka. Dla potrzeb dalszego planowania rozwoju turystyki na Kubie, przede wszystkim w jej aspekcie przestrzennym, wydzielono sześć podstawowych regionów turystycznych. Są to: Hawana, Varadero, Ciego de Avilla, Holugin, Santiago de Cuba oraz Cayo Largo Sur, które bardzo często określane są jako bieguny wzrostu (Núñez, Fernández, 2011). Wydzielone jednostki przestrzenne charakteryzują się bardzo dobrym zagospodarowaniem turystycznym - tu znajduje się ok. 70\% miejsc noclegowych - oraz dużym natężeniem ruchu turystycznego (88\% turystów zagranicznych). Niestety, dostępna statystyka nie pozwala przeprowadzić szczegółowych analiz statystyczno-przestrzennych, ponieważ nie są publikowane informacje na temat liczby i rodzaju podmiotów gospodarczych działających w poszczególnych prowincjach. Spośród wyżej wymienionych jednostek wszystkie poza Hawaną i Santiago de Cuba są regionami turystyki wypoczynkowej, w których indywidualna działalność gospodarcza rozwija się bardzo słabo. Natomiast w historycznych miastach, takich jak: Hawana, Santiago de Cuba, Trynidad, Cienfuegos, obsługa ruchu turystycznego jest organizowana w oparciu o indywidualne podmioty gospodarcze (casas particulares, paladares). Do dalszej analizy zostały wybrane tylko trzy regiony, w których ten rodzaj zagospodarowania turystycznego jest znaczny.

Vinales - największa przyrodnicza atrakcja Kuby, położona w zachodniej części wyspy, w prowincji Pinar del Rio, to park narodowy wpisany na listę UNESCO, którego głównymi atrakcjami są formy krasowe: jaskinie i mogoty. Jest to obszar odwiedzany przede wszystkim przez turystów jednodniowych podczas wycieczek fakultatywnych organizowanych dla osób odpoczywających w Hawanie bądź w Varadero. Główną formą zagospodarowania turystycznego są casas particulares (120 obiektów) oraz trzy hotele (173 pokoje). Przedsiębiorczość mieszkańców Vinales i okolicy nie ogranicza się jedynie do świadczenia usług noclegowych i gastronomicznych, Kubańczycy zapewniają także usługi transportowe i przewodnickie. Perspektywicznie Vinales ma pozostać centrum ekoturystycznym, w którym nie przewiduje się powstawania dużych kompleksów hotelowych. Podobna sytuacja występuje w drugim regionie tej prowincji, jakim jest Las Terrazas. Jest to obszar przyrody chronionej o powierzchni 5 tys. ha, 
położony w odległości $60 \mathrm{~km}$ od Hawany. W bezpośrednim sąsiedztwie parku wybudowano kompleks hotelowy. Inicjatywa powstania tego obiektu należała do Ministerstwa Turystyki, ale była konsultowana z przedstawicielami lokalnej społeczności, która zarządza tym obiektem. Obecne zyski z prowadzonej działalności gospodarczej przeznaczane są w 50\% na spłatę kredytu, w 40\% na fundusz rozwoju lokalnego i w 10\% na opiekę medyczną.

Na największą skalę przedsiębiorczość rozwija się w najstarszym, a zarazem najważniejszym ośrodku turystycznym, jakim jest Hawana, główne centrum turystyki miejskiej. Z historycznego punktu widzenia turystyka odgrywała najważniejszą rolę $\mathrm{w}$ okresie międzywojennym, miasto było wtedy głównym obszarem recepcji turystycznej bogatych Amerykanów na Karaibach. W okresie tym głównymi produktami turystycznymi miasta były rum i kasyna. Hawana dysponowała największym potencjałem w zakresie infrastruktury turystycznej. Aktualnie jest to jeden z najważniejszych regionów turystycznych Kuby, charakteryzujący się bardzo dobrym zagospodarowaniem turystycznym, w którym w 2010 r. udzielono 2,7 mln noclegów. Turystycznym centrum miasta jest Old Havana, przez wiele dziesięcioleci zaniedbywana przez władze kraju. Dopiero kiedy w 1982 r. została wpisana na Listę światowego dziedzictwa kulturowego i przyrodniczego UNESCO, podjęto działania zmierzające do przekształcenia tej części miasta w największą atrakcję turystyczną Kuby. W przypadku Hawany występuje terytorialne zróżnicowanie wielkości i charakteru obiektów noclegowych: w starej, historycznej części miasta (Havana Vieja) hotele są małe, butikowe i nienależące do żadnej sieci hotelowej, natomiast Vedado i Miramar mają duże, sieciowe obiekty.

Znacznie mniejszym ośrodkiem turystycznym jest Trynidad - miasto kolonialne wpisane na listę UNESCO i leżące na terenie prowincji Sancti Spiritus, położone w południowej części wyspy w odległości ok. $80 \mathrm{~km}$ od wybrzeża. Jest ono miejscem turystyki kulturowej. Baza noclegowa składa się w większości z casas particulares oraz jednego hotelu Iberostar Grand Hotel Trynidad z 40 pokojami (Peters, 2002). Natomiast w niewielkiej odległości od miasta na południowym wybrzeżu wyspy znajduje się plaża Ancon. Jest to półwysep, na którym zlokalizowane są dwa hotele (cztero- i trzygwiazdkowy) dysponujące łącznie 520 pokojami. Na wybrzeżu położony jest jeszcze jeden kompleks hotelowy mający 131 pokoi. Podobnie jak w Vinales przeważa tu turysta jednodniowy odpoczywający w enklawach turystycznych, takich jak Cayo Coco czy Cayo Santa Maria lub w ośrodkach otwartych - Hawana i Varadero.

Drugim bardzo popularnym rodzajem działalności przedsiębiorców na Kubie są punkty gastronomiczne - paladares. Powstawały one w tym samym czasie, co casas particulares. Głównym motywem zakładanie tego typu działalności było uzupełnienie olbrzymiej luki na krajowym rynku oraz możliwości uzyskania dodatkowego dochodu. Już od początku swego istnienia palodores borykały się z problemami dotyczącymi zaopatrzenia w produkty żywnościowe, np. dopiero niedawno zezwolono w tego typu punktach gastronomicznych podawać wołowinę i owoce morza. Do dnia dzisiejszego przedsiębiorcy są nękani licznymi kontrolami wynikającymi z chęci ograniczenia działania szarej strefy, a zwłaszcza nielegalnego handlu i kradzieży z przedsiębiorstw państwowych produktów żywnościowych. Paladares powstają przede wszystkim w miastach, czyli tam, gdzie jest duże zapotrzebowanie na tego typu usługi ze strony ludności miejscowej i turystów. Są one także lokalizowane przy głównych trasach komunikacyjnych oraz przy pojedynczych atrakcjach turystycznych, takich jak: jaskinia Los Indianos, Mural Prehistoria czy Playa Pilar. Paladares nie powstają przy ośrodkach wypoczynkowych, ponieważ w większości są to obiekty oferujące wypoczynek all inclusive. Nowym trendem w powstawaniu restauracji i barów oferujących miejscową kuchnię jest lokalizowanie ich w centrach handlowo-usługowych funkcjonujących na terenie enklaw turystycznych. Za przykład może posłużyć Pueblo Las Dunas i Estrella na Cayo Santa Maria. 


\section{Podsumowanie}

Kryzys gospodarczy lat 90. na Kubie był impulsem do wprowadzania szeregu reform dotyczących wszystkich aspektów życia społeczno-gospodarczego wyspy.

Przedsiębiorczość na Kubie rozwijana jest z kilku powodów. Pierwszym z nich jest wzrost liczby bezrobotnych na rynku pracy, kryzys w sektorze państwowych przedsiębiorstw, funkcja uzupełniająca rynek usług zarówno dla ludności miejscowej, jak i dla turystów, szeroko pojęty rozwój funkcji turystycznej regionów. Od początku lat 90. obserwuje się wzrost liczby podmiotów gospodarczych prywatnego sektora, ale w niektórych latach notuje się spadki wiążące się z rezygnacją z działalności gospodarczej, wynikającą ze zbyt dużych obciążeń finansowych (podatki, opłaty za licencję). Wysokie obciążenie finansowe wynikające ze zobowiązań w stosunku do państwa są poważnym utrudnieniem dla prowadzących samodzielną działalność gospodarczą.

Sektorem, w którym dynamicznie rozwijają się różne formy przedsiębiorczości, jest rynek turystyki przyjazdowej. Wynika to bezpośrednio z ogólnej strategii rozwojowej kraju, w której to turystyka jest podstawowym sektorem gospodarczej działalności. Na Kubie dominuje turystyka wypoczynkowa w hotelach nadmorskich typu all inclucive. Ukierunkowana jest ona na wymagającego, bogatego turystę z Europy Zachodniej lub Kanady. Alternatywnym rodzajem wypoczynku jest samodzielne podróżowanie i poznawanie ,,autentycznej Kuby”. Jest to nowy trend w turystyce na Karaibach, powszechnie utożsamianej z enklawami turystycznymi. Odpowiedzią na ten rodzaj turystyki jest wzrost przedsiębiorczości mieszkańców Kuby, którzy chcą zapewnić potencjalnemu turyście kompleksowy odpoczynek (usługi noclegowe - casas particulares, gastronomiczne - paladares, transportowe i przewodnickie). Największa liczba podmiotów gospodarczych, działających w branży turystycznej, powstaje w miastach historycznych (Hawana, Trynidad, Cienfuegos) oraz na obszarach ekoturystycznych (Vinales, Las Terrazas, Półwysep Zapata). Natomiast ścisłe enklawy turystyczne, takie jak: Cayo Coco, Cayo Largo del Sur, są praktycznie pozbawione miejscowej ludności oraz wszelkich przejawów indywidualnej przedsiębiorczości.

Do najważniejszych czynników ograniczających rozwój przedsiębiorczości na Kubie zalicza się: bardzo duże obciążenia finansowe (podatki i opłaty licencyjne), częste kontrole, ograniczenia dotyczące kanałów marketingu i reklamy i przede wszystkim dystrybucji.

Pomimo wprowadzanych reform rola państwa w systemie społeczno-gospodarczym wciąż pozostaje wiodąca (Pickel, 1998), rynek kubański pozostaje podporządkowany władzom Kuby. Państwo pozostawia sobie podejmowanie decyzji w sprawie ustanawiania ram prawnych dla życia politycznego, gospodarczego, prawa pracy oraz zagwarantowania bezpieczeństwa społecznego. Zarówno w trakcie, jak i po zakończeniu reform gospodarczych rola państwa będzie dominująca, a przedsiębiorczość będzie rozwijała się na tyle, na ile władze pozwolą lub będzie to im potrzebne.

\section{Literatura \\ References}

Cervino, J., Cubillo, J.M. (2005). Hotel and tourism development in Cuba. Opportunities, management, challenges, and future trends. Cornell Hotel and Restaurant Administration Quarterly, 46(2), 223-246.

Eckstein, S. (2009). Remitances and their unintended in Cuba. World Development, 38(7). 1047-1055. DOI:10.1016/j.worlddev.2009.12.006.

Gustafsson, T. (2011). Kuba. Carlsson. Svenska.

Kederstedt, D. (2012). Stenhård konkurrens när Kuba privatiserar. Svenska dagbladet. www.svd.se/naringsliv/nyheter/varlden/stenhard-konkurrens-nar-kuba privatiserar_7634192.svd.Published, 2012-11-04. 
Mowforth, M. \& Munt, I. (2009). Tourism and Sustainability, Development, Globalisation and New Tourism in the Third World 3rd Edition. Routledge. London, UK.

Núñez, G.G., Fernández, R.O. (2011). Cuba y el turismo norteamericano. Analisis de potencialidades y de impactos en la región caribeña. Cuba Futures Series. 141-199.

Page, S. (2011). Tourism management, an introduction 4th edition. Elsevier Ltd. Oxford, UK.

Pérez-López, J.F. (1995). Cuba's Second Economy: From Behind the Scenes to Center Stage. New Brunswick, NJ: Transaction Books.

Pérez-López, J.F. (2001). Cuba's Socialist Economy: the Mid-1990s. Cuban Communism, Tenth Edition, I.L. Horowitz, J. Suchlicki (ed.). New Brunswick: Transaction Publishers, 205-236.

Peters, P. (2002). International tourism. The new engine of the cuban economy, Lexington Institute.

Peters, P. (2012a). A Viewer's Guide to Cuba's Economic Reform Lexington Institute.

Peters, P. (2012b). Cuba's Entrepreneurs: Foundation of a New Private Sector. Lexington Institute.

Pickel, A. (1998). Is Cuba Different? Regime Stability, Social Change, and the Problem of Reform Strategy. Communist and Post-Communist Studies, 31(1). 75-90.

Rettinger, R. (2012). Konkurencyjność regionów turystycznych na przykładzie Dominikany. W: M. Drgas, J. Knopek (red.), Gospodarcze problemy Ameryki Łacińskiej, seria „Biblioteka Studiów Latynoamerykańskich, t. 3. Toruń: Wydawnictwo Adam Marszałek, 221-244.

Rosendahl, M. (1997) Inside the Revolution: Everyday Life in Socialist Cuba, Ithaca, NY: Cornell University Press.

Scarpaci, J.L. (1995). The Emerging Food and Paladar Market in Havana. Cuba in Transition-Volume 5, Washington, D.C.: Association for the Study of the Cuban Economy. 74-84.

Scarpaci, J.L. (2009). Fifteen Years of Entrepeneurship in Cuba: Challenges and Opportunities. Cuba in Transition, 19, Washington D.C., 349-353.

Spadoni, P. (2003). The role of the United States in the Cuban economy. Cuba in Transition 13. Washington: Association for the Study of the Cuban Economy.

Spencer, R. (2010). Development Tourism: Lessons from Cuba. Ashgate Publishing Group. Surrey, England. Taylor, H.L., McGlynn, L. (2009). International tourism in Cuba: Can capitalism be used to save socialism, Futures 41 Elsevier, 405-413.

Uriarte, M. (2008). Social impact of the economic measures. W: P. Brenner et al. (ed.), Reinventing the revolution: A contemporary Cuba reader. Boulder: Rowman and Littlefield. 285-292.

Renata Rettinger, dr, adiunkt na Uniwersytecie Pedagogicznym im. KEN w Krakowie, Instytut Geografii. Autorka w swoich badaniach koncentruje się na problematyce rozwoju turystyki w regionie karaibskim. W problematyce badawczej przeważają tematy dotyczące wielkości i przestrzennego zróżnicowania zagospodarowania i ruchu turystycznego, a w szczególności kierunki rozwoju turystyki. W opracowaniach przewija się także tematyka enklaw turystycznych jako dominującej formy zagospodarowania turystycznego na Karaibach w kontekście rozwoju zrównoważonego i turystyki pro-poor.

Renata Rettinger, $\mathrm{PhD}$, Adiunkt (an assistant professor), Pedagogical University of Cracow, Institute of Geography.

Author in her research concentrates on the problems on tourism development in $\mathrm{Ca}$ ribbean region. The research issues on the size and spatial differentiation of tourist infrastructure and tourism volume itself together with the directions of the tourism development dominate. The research topics also include the issue of tourist enclaves as a dominating form of tourist infrastructure in Caribbean in the light of sustainable development and pro-poor tourism.

Adres/Address: Uniwersytet Pedagogiczny im. Komisji Edukacji Narodowej w Krakowie

Instytut Geografii

ul. Podchorążych 2

30-084 Kraków, Polska

e-mail: rettinger@onet.eu 